\title{
Chemical Analysis of the Edible Mushroom Tricholoma populinum: Steroids and Sulfinyladenosine Compounds
}

\author{
Bernadett Kovácsa ${ }^{\mathrm{a}}$,Zoltán Béni ${ }^{\mathrm{b}}$, Miklós Dékány ${ }^{\mathrm{b}}$, Orsolya Orbán-Gyapai ${ }^{\mathrm{a}}$, Izabella Sinka ${ }^{\mathrm{c}}$, \\ István Zupkóc , Judit Hohmanna,d*and Attila Ványolós ${ }^{a^{*}}$ \\ ${ }^{a}$ Department of Pharmacognosy, University of Szeged, Eötvös u. 6, 6720 Szeged, Hungary \\ ${ }^{b}$ Spectroscopic Research, Gedeon Richter Plc., Gyömrői út 19-21, H-1103 Budapest, Hungary \\ ${ }^{c}$ Department of Pharmacodynamics and Biopharmacy, University of Szeged, Eötvös u. 6, 6720 Szeged, Hungary \\ ${ }^{d}$ Interdisciplinary Centre for Natural Products, University of Szeged, Eötvös u. 6, H-6720 Szeged, Hungary
}

hohmann@pharm.u-szeged.hu; vanyolosa@pharmacognosy.hu

Received: March 20 ${ }^{\text {th }}, 2017$; Accepted: XX, 2017

Ten compounds have been identified in the methanol extract of cottonwood mushroom (Tricholoma populinum J.E. Lange), 9 of them for the first time in this species. Besides adenosine (8) and nicotinamide (7) the isolated compounds were ergostane type steroids (1-6) and rare sulfinyladenosine constituents (9 and 10). The chemical structures of these compounds were elucidated by means of extensive spectroscopic methods (NMR and MS). Compounds 3-6 were evaluated for their potential antiproliferative activity against human cancer cell lines using the 3-(4,5-dimethylthiazol-2-yl)-2,5-diphenyltetrazolium bromide (MTT) assay. The xanthine oxidase (XO) inhibitory activity of 7-10 has been examined by spectrophotometric method. Cerevisterol (3), its methylated derivative (5) and 3-glycoside of ergosterol peroxide (6) showed significant antiproliferative activity on human breast cancer cell lines.

Keywords: Mushroom, Tricholoma populinum, Antiproliferative, Sulfinyladenosine, Steroids.

For centuries Basidiomycetes mushrooms have been used as food material and also for their various beneficial properties by several traditional medicines around the world. Nowadays mushrooms are recognized as functional foods with high nutritional value, appreciable vitamin and mineral content, favorable essential amino acid profile; furthermore there is a rising interest in exploring the biologically active compounds of mushrooms, since they represent a rich source of structurally diverse metabolites with potential medical application [1].

In our ongoing research program, aiming the evaluation of Hungarian macrofungi in terms of their chemical composition and pharmacological activity, extracts of cottonwood mushroom (Tricholoma populinum J.E. Lange) were found to exhibit XO inhibitory property [2] and antiproliferative activity against several human cancer cell lines [3]. T. populinum, member of the fairly large genus of Tricholoma, is a less known relative of the distinguished species of T. matsutake and T. magnivelare; it grows on sandy soil under cottonwood (Populus sp.) trees near a source of water. While $T$. matsutake and $T$. magnivelare are both highly popular among consumers in Asia and America because of their unique spicy odor and taste, T. populinum is less significant as food material. Even if it has a lower culinary value than the above mentioned species, T. populinum is however consumed in North America by Salish Indian people from British Columbia [4] and the Native American tribe of Taos Pueblo in New Mexico [5]. Furthermore, according to Lentini and Venza (2006) sporocarps of cottonwood mushroom ("funci di chiuppu") are eaten by locals in Sicily, during the fall season [6]. Our literature survey on the chemistry and pharmacology of cottonwood mushroom revealed that little is known about this species; Kreisel et al. found that it contains egosterol peroxide, which demonstrated immunosuppressive activity [7]. The primary goals of the present study were to explore the chemical profile of cottonwood mushroom and to examine the pharmacological activity of the isolated compounds.

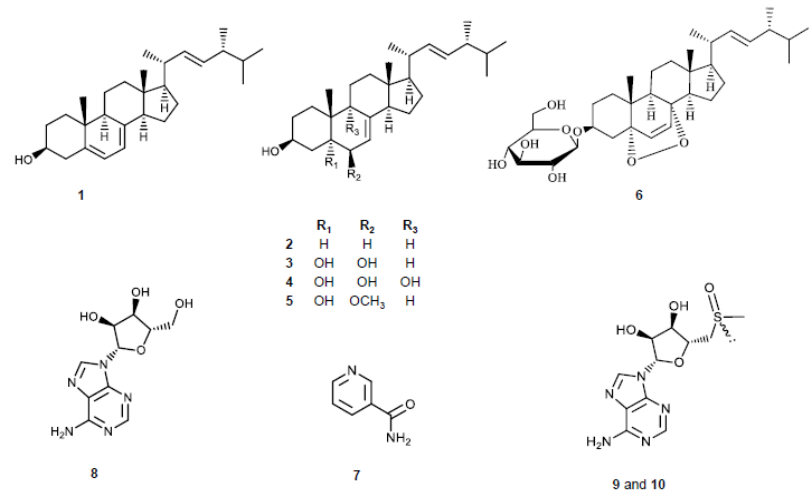

Figure 1: Structures of compounds 1-10 isolated from Tricholoma populinum.

The investigation of the methanol extract obtained from the lyophilized fruiting bodies of cottonwood mushroom led to the isolation of 10 compounds (Figure 1.). The fungal extract was subjected to solvent-solvent partition between aqueous $\mathrm{MeOH}$ and $n$-hexane, followed by extraction with chloroform. The obtained $n$ hexane and chloroform extracts were purified using combined chromatographic methods including column chromatography, flash chromatography, rotational planar chromatography and reversedphase HPLC. Compounds $\mathbf{1}$ and $\mathbf{2}$ were identified by comparing their chromatographic and spectroscopic data with those of authentic samples. Compounds $\mathbf{3 - 1 0}$ were structurally characterized on the basis of NMR and MS spectroscopic data and were confirmed by comparing them to those reported earlier for these compounds.

All compounds have been identified for the first time in $T$. populinum, except nicotinamide (7), which has been detected by Turner et al. [4] in cottonwood mushroom samples collected in 
British Columbia (Canada). Among the isolated compounds six constituents (1-6) belong to the group of triterpene steroids of ergostane skeleton. Ergosterol (1) and 3 $\beta$-hydroxyergosta-7,22diene (2) are common steroids with a widespread distribution among fungal species, as well as cerevisterol (3), and $3 \beta, 5 \alpha, 6 \beta, 9 \alpha-$ tetrahydroxyergosta-7,22-diene (4), which are di- and trihydroxlated derivatives of $3 \beta$-hydroxyergosta-7,22-diene (2). Compound 5, a methylated derivative of $\mathbf{3}$, has been previously isolated from the medicinal mushroom Agaricus blazei by Kawagishi et al. [8]. The steroid derivative 6, identified by Takaishi et al. in Hericium erinaceus is an ergosterol-3-glucoside, which has a peroxide linkage between $\mathrm{C}_{5}$ and $\mathrm{C}_{8}$ [9]. Besides nicotinamide (7), the main constituents of the chloroform extract proved to be the adenosine type compounds of 8,9 and $\mathbf{1 0}$.

Whilst adenosine (8) is commonly found in living organisms, the methylsulfinyladenosine derivatives $\mathbf{9}$ and $\mathbf{1 0}$ represent a fairly rare subclass of secondary metabolites. According to our literature overview this type of compounds has only been detected in a single fungal, a plant species, and two marine organisms so far. Compounds $\mathbf{9}$ and $\mathbf{1 0}$ were first isolated as inseparable epimeric mixture from Ganoderma lucidum, and have been characterized as inhibitors of platelet aggregation [10]. In 1997 these compounds were also identified in the ethanol extract of Sauropus androgynous, a cultivated plant native to Southeast Asia [11]. The other known sources of sulfinyladenosine compounds are the marine ascidians Herdmania momus, which synthesizes four complex adenosides with bromines in their structures [12], and Atriolum robustum, which contains a metabolite with methoxyacrylic acid group linked to the sulfinyladenosine moiety [13]. As compared to the findings of Kawagishi et al. (1993) however, the fruiting bodies of $T$. populinum contain approx. 80 times higher amount from these sulfinyladenosines than G. lucidum [10].

The isolated steroids 3-6 were evaluated for their potential cytotoxic activity by MTT method on three different human breast cancer cell lines (Table 1). Compounds $\mathbf{3}$ and $\mathbf{6}$ proved to be the most active against T47D cells, while the methylated derivative of cerevisterol (5) demonstrated significant activity on MDA-MB-231 cells.
Table 1: Antiproliferative activity of compounds 3-6 on human cancer cell lines

\begin{tabular}{ccccc}
\hline Compds. & \multicolumn{4}{c}{ Cell growth inhibition (\%) \pm SEM } \\
& & MCF7 cells & T47D cells & $\begin{array}{c}\text { MDA-MB-231 } \\
\text { cells }\end{array}$ \\
\hline $\mathbf{3}$ & $10 \mu \mathrm{M}$ & $-*$ & $38.4 \pm 0.6$ & - \\
& $30 \mu \mathrm{M}$ & - & $50.2 \pm 1.6$ & - \\
$\mathbf{4}$ & $10 \mu \mathrm{M}$ & - & - & - \\
& $30 \mu \mathrm{M}$ & - & - & - \\
$\mathbf{5}$ & $10 \mu \mathrm{M}$ & - & $20.1 \pm 1.4$ & $25.7 \pm 1.5$ \\
& $30 \mu \mathrm{M}$ & - & $23.7 \pm 2.4$ & $54.7 \pm 1.6$ \\
$\mathbf{6}$ & $10 \mu \mathrm{M}$ & - & - & - \\
& $30 \mu \mathrm{M}$ & $37.17 \pm 2.49$ & $46.0 \pm 1.4$ & - \\
\hline
\end{tabular}
for clarity

Among the three cell lines, MCF7 proved to be the least susceptible against the isolated compounds; however $\mathbf{6}$ exerted moderate activity on this cell line as well. Compounds 7-10 were evaluated for their potential XO inhibitory activity, though our results indicate that they do not possess inhibitory activity on this enzyme.

The present study is the first comprehensive chemical analysis of the edible mushroom Tricholoma populinum. The detailed investigation of the methanol extract of $T$. populinum led to the isolation and identification of 10 compounds. Nine of these are identified for the first time in this species. The low-molecule chemical profile of cottonwood mushroom includes rare sulfinyladenosine compounds (9 and 10) and ergostane type triterpenoids (1-6). Biological evaluation of the isolated compounds showed that cerevisterol (3) and its methylated derivative (5), as well as 3-glycoside of ergosterol peroxide (6) have significant antiproliferative activity on some human breast cancer cell lines. Based on the results obtained the current study makes a valuable contribution to the chemistry and pharmacology of the edible mushroom $T$. populinum.

Supplementary data: The electronic supplementary material contains information on isolation and structural determination of compounds 3-10, and the biological assays performed.

Acknowledgments - The authors thank Éva Bata Hullmann (Hungarian Mycological Society) for her help in the identification and collection of mushroom material.

\section{References}

[1] Lindequist U, Niedermeyer THJ, Jülich WD. (2005) The pharmacological potential of mushrooms. Evidence-Based Complementary and Alternative Medicine, 2, 285-299.

[2] Ványolós A, Orbán-Gyapai O, Hohmann J. (2014) Xanthine oxidase inhibitory activity of Hungarian wild-growing mushrooms. Phytotherapy Research, 28, 1204-1210.

[3] Ványolós A, Kovács B, Bózsity N, Zupkó I, Hohmann J. (2015) Antiproliferative activity of some higher mushrooms from Hungary against human cancer cell lines. International Journal of Medicinal Mushrooms, 17, 1145-1149.

[4] Turner NJ, Kuhnlein HV, Egger KN. (1987) The cottonwood mushroom (Tricholoma populinum): a food resource of the Interior Salish Indian peoples of British Columbia. Canadian Journal of Botany, 65, 921-927.

[5] Arora D. (1991) All That the Rain Promises, and More...: A Hip-Pocket Guide to Western Mushrooms. Berkeley: Ten Speed Press.

[6] Lentini F, Venza F. (2006) Wild food plants of popular use in Sicily. Jornal of Ethnobiology and Ethnomedicine, 3 (15), 1-12.

[7] Kreisel H, Lindequist U, Horak M. (1990) Distribution, ecology and immunosuppressive properties of Tricholoma populinum (Basidiomycetes). Zentralblatt für Mikrobiologie, 145, 393-396.

[8] Kawagishi H, Katsumi R, Sazawa T, Mizuno T, Hagiwara T, Nakamura T. (1988) Cytotoxic steroids from the mushroom Agaricus blazei. Phytochemistry, 27, 2777-2779.

[9] Takaishi Y, Uda M, Ohashi T, Nakano K, Murakami K, Tomimatsu T. (1991) Glycosides of ergosterol derivatives from Hericium erinaceus. Phytochemistry. 30, 4117-4120.

[10] Kawagishi H, Fukuhara F, Sazuka M, Kawashima A, Mitsubori T, Tomita T. (1993) 5'-Deoxy-5'-methylsulphinyladenosine, a platelet aggregation inhibitor from Ganoderma lucidum. Phytochemistry, 32, 239-242.

[11] Wang PH, Lee SS. (1997) Active chemical constituents from Sauropus androgynous. Journal of the Chinese Chemical Society, 44, 145-149

[12] Li JL, Kim EL, Wang H, Hong J, Shin S, Lee C-K, Jung JH. (2013) Epimeric methylsulfinyladenosine derivatives from the marine ascidian Herdmania momus. Bioorganic \& Medicinal Chemistry Letters, 23, 4701-4704.

[13] Kehraus S, Gorzalka S, Hallmen C, Iqbal J, Müller CE, Wright AD, Wiese M, König GM. (2004) Novel Amino Acid Derived Natural Products from the Ascidian Atriolum robustum: Identification and Pharmacological Characterization of a Unique Adenosine Derivative. Journal of Medicinal Chemistry, 47, 2243-2255. 